\title{
Women's Representation and the Gendered Pipeline to Power
}

\author{
DANIELLE M. THOMSEN University of California, Irvine \\ AARON S. KING University of North Carolina Wilmington
}

\begin{abstract}
7 he leading explanation for the underrepresentation of women in American politics is that women are less likely to run for office than men, but scholars have given less attention in recent years to the gender makeup of the pipeline to elected office. We examine the gendered pipeline to power across three potential candidate pools: lower-level officeholders, those named in newspapers as likely candidates, and lawyers who made political contributions. We find some evidence that women are less likely to seek elected office; however, the dearth of women in the pipeline plays a much greater role in the lack of women candidates. For the gender disparity in candidates to close, women have to be far more likely to run for office than men, particularly on the Republican side. Our results highlight the need to consider the gendered pipeline to power alongside rates of entry in studies of women's underrepresentation.
\end{abstract}

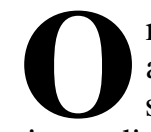
ne of the central puzzles in the study of gender and politics is why women are underrepresented in elected office. Scholars of comparative politics have examined a range of structural and institutional factors including electoral systems, gender quotas, and labor force participation. In the American context, the first wave of research on female underrepresentation similarly pointed to the political opportunity structure and the absence of women in the careers that feed into politics. The finding that "when women run, they win" at equal rates as men further spurred the shift away from voter biases (Burrell 1994; Carroll 1994; Darcy, Welch, and Clark 1994; DuerstLahti 1998; Seltzer, Newman, and Leighton 1997). ${ }^{1}$ The

Danielle M. Thomsen (D) Assistant Professor, Department of Political Science, University of California, Irvine, dthomsen@uci.edu Aaron S. King (iD Associate Professor, Department of Public and International Affairs, University of North Carolina Wilmington, kinga@uncw.edu

We thank Andrea Aldrich, Tiffany Barnes, Sue Carroll, Mirya Holman, Kris Kanthak, Mona Krook, Tali Mendelberg, Diana O'Brien, Jennifer Piscopo, Spencer Piston, Jessica Preece, Kira Sanbonmatsu, Dawn Teele, Ian Turner, and four anonymous reviewers for helpful comments and feedback. We are also grateful to seminar participants at the Empirical Study of Gender Research Network meeting, the PIPE workshop at the University of Southern California, and Rutgers University. We thank Adam Bonica, Steve Rogers, Maya Sen, and Jason Windett for generously sharing data. Replication materials can be found on Dataverse at: https://doi.org/10.7910/DVN/FCZDKD.

Received: June 21, 2019; revised: April 24, 2020; accepted: May 25, 2020.

\footnotetext{
${ }^{1}$ Although women win as often as men, others have also cast doubt on the notion that elections are gender neutral (i.e., Anzia and Berry 2011; Fulton 2012; Lazarus and Steigerwalt 2018; Pearson and McGhee 2013). Sanbonmatsu (2002) finds that voters have a "baseline gender preference," and Mo (2015) identifies implicit biases among voters. A host of stereotype studies indicate that female candidates are perceived through a gendered lens (Bauer 2015; Cassese and Holman 2018; Ditonto, Hamilton, and Redlawsk 2014; Holman, Merolla, and Zechmeister 2016; Schneider and Bos 2014). Teele, Kalla, and Rosenbluth (2018) find limited evidence of outright discrimination or double standards but show that voter and elite preferences result in a double bind that hinders women candidates.
}

expectation at the time was that as more women entered the pipeline professions and ran as incumbents, women's representation would increase. However, in the years that followed, the number of women in office stagnated, and levels of representation across offices have remained far below parity. Even after the notable gains in 2018, $76 \%$ of members of Congress, $82 \%$ of governors, $71 \%$ of state legislators, and $78 \%$ of mayors are men (CAWP 2019).

Since then, research on women's underrepresentation in the United States and abroad has taken different trajectories. While a large comparative literature grew around the adoption of gender quotas, scholars in the candidate-centered American context turned to individual-level differences between men and women and the study of candidate emergence in particular. ${ }^{2}$ For the past two decades, the leading explanation for the dearth of women in American politics has been that women are less likely to run for office than similarly situated men. Scholars have identified a variety of reasons for why this is the case. The most prominent of these highlights a gender disparity in political ambition. Lawless and Fox (2005; 2010; Fox and Lawless 2010; 2014) have been at the forefront of ambition research. In a two-wave study of nearly 4,000 men and women in the most common careers that feed into politics, including law, business, education, and political activism, they find that women are less likely to consider running for office and less likely to be encouraged to run than their male counterparts. They describe a persistent winnowing effect that occurs over multiple stages of the candidate emergence process, which ultimately results in fewer women who run.

Others attribute women's lower rates of entry in the US to gender differences in recruitment patterns and election aversion. Several studies show that party

\footnotetext{
${ }^{2}$ In general, comparativists tend to examine variation in the percentage of women in office cross-nationally and over time rather than individual-level attitudes or behavior. However, there are a growing number of individual-level studies of political ambition outside the US that are discussed below (see also Piscopo and Kenny 2020).
} 
leaders fail to recruit women as often as men and screen ambitious women out of seats they believe women cannot win (Crowder-Meyer 2013; Fox and Lawless 2010; Niven 1998; Sanbonmatsu 2006). Carroll and Sanbonmatsu (2013) find that women's decision to seek office is influenced more by their relationships with others, and gender biases in recruitment efforts may disproportionately depress female candidacies as a result. Kanthak and Woon (2015) instead point to the competitive nature of campaigns and gender differences in election aversion. They use a unique experimental design and show that women are equally likely to volunteer as a candidate when the representative is chosen randomly but less inclined to do so when the representative is chosen by an election. Preece and Stoddard (2015) additionally demonstrate that priming individuals to consider political competition has a negative effect on women's interest in politics but not on men's interest (see also Schneider et al. 2016).

All of these factors likely play a role in women's absence from politics. Yet by comparison, the gender makeup of the pipeline to office has received virtually no attention in recent studies of female underrepresentation. There are several reasons why the gender makeup of the pool has been overlooked. For one, most samples of potential candidates are intentionally gender balanced. Lawless and Fox (2010, 37) disproportionately stratified their sample by sex to include equal numbers of women and men. Their goal was not to replicate the gender makeup of these professions (Lawless 2012, 25; Lawless and Fox 2010, 177), and the sample allowed them to make comparisons within and between subgroups of men and women. Kanthak and Woon $(2015,597)$ similarly recruited genderbalanced groups in their analysis of election aversion. While gender-balanced pools do increase the number of women in our samples (and reflect the makeup of the public), this sampling choice has hindered our ability to examine gender disparities in supply alongside gender disparities in candidate emergence.

The few studies that do use gender-imbalanced samples give little attention to the gender skew and instead focus on rates of entry (Maisel and Stone 2014; Mariani 2008). Conversely, others who consider disparities in the supply of candidates either do not explore the actual decision to run for office or do not address how much more likely to run women would need to be to reach parity with men. Crowder-Meyer and Lauderdale (2014) use a novel empirical design and identify potential male and female candidate pools based on the characteristics of high-level officeholders. They show that the proportion of women in the Democratic pool of potential candidates is now two to three times larger than the proportion of women in the Republican pool, but they do not analyze who runs for office. Thomsen (2017) and Brown et al. (2019) examine the decision to run for Congress across state legislators, but neither delves into the level of entry that would be needed for parity.

In sum, there are no studies that place the decision to run for office in the context of the gender makeup of the potential candidate pool. The problem with this is that the representational implications of gender disparities in rates of entry are closely tied to gender disparities in the eligibility pool. For example, Lawless and Fox (2010) find that $7 \%$ of women and $12 \%$ of men in their sample ran for office, and Mariani (2008) finds that $4 \%$ of men and $2 \%$ of women in his sample did so. Yet we might wonder what these averages are a percentage of. If women comprise $20 \%$ of the pool, these gaps have different consequences for the number of female candidates than if women comprise $40 \%$ of the pool. Moreover, even across studies of candidate emergence, the outcome of interest is rarely the actual decision to run for office. Scholars have mostly focused on disparities in the precursors to and correlates of running for office, such as the consideration of a candidacy or attraction to a political career, but we know less about rates of entry across eligible or likely candidates. As a result, we lack satisfactory answers to basic but important questions like whether the gender gap in candidates would close if women were as likely to run as their male counterparts.

In this article, we seek to spark a renewed discussion of how the gendered pipeline to power matters at least as much as rates of entry, if not more, for future prospects of gender parity. We examine the gender makeup of three pools of potential candidates: lowerlevel officeholders, those named in newspapers as likely candidates, and lawyers who donated to political campaigns. The main strength of these datasets is that we can analyze actual rates of entry in conjunction with the gender composition of the pool. Another advantage is that our data capture traditional and nontraditional pathways to office and include individuals with different propensities to run. We find some evidence that women are less likely to run for office than men; however, the dearth of women in the pipeline plays a much greater role in the lack of women candidates. Depending on the office, women have to be at least three times more likely to run than their male counterparts for the gender disparity in candidates to close. Due to the stark gender imbalance in the GOP bench, Republican women have to be five or six times more likely to run than men for the number of Republican women candidates to equal the number of Republican men.

While the decision to run for office is less applicable in contexts where parties control nominations, our findings have implications for comparative politics as well. As Piscopo and Kenny $(2020$, 5) write, "The assumption that women lack political ambition relative to men has gone global." The growing number of studies of political ambition outside the United States also use similar empirical designs (i.e., Allen and Cutts 2017; 2020; Davidson-Schmich 2016; Kage, Rosenbluth, and Tanaka 2019; Norris and Lovenduski 1995; Piscopo and Kenny 2020; Pruysers and Blais 2017; 2019; Schwindt-Bayer 2011). Due to the different methods of candidate selection across countries, the dependent variable ranges from considering a candidacy to being willing to stand for office to accepting a party nomination. Yet there is less attention to the decision to stand for office itself, and gender-balanced samples 
are common. ${ }^{3}$ Some pipelines may, in fact, include half women but most likely do not, and this variation matters for whether gender parity in ambition or party recruitment is sufficient to close the gender gap in candidates. One extension of our results is that party gatekeepers may need to be more likely to recruit women than men to achieve gender balance in party lists. Indeed, Davidson-Schmich (2016) finds that, in Germany, women in parties with gender parity quotas are more likely to be asked by the party to run than their male counterparts (see also Allen and Cutts 2017). Thus, while the outcome of interest will differ across settings, the central question we are posing - Is gender parity enough? - is relevant to scholars of American and comparative politics alike. Our focus is on female underrepresentation in the United States, but we think the gender makeup of the pool of potential candidates is a key part of the answer to this question across political contexts.

\section{THE MALE ELIGIBILITY POOL}

The main reason why the gender makeup of the pipeline deserves renewed attention is that the vast majority of potential candidate pools remain heavily skewed by gender. Even if women were as likely to run as men, the likelihood that a candidate would be a woman is low due to the much smaller number of women in the pool. For one, lower-level offices, a common stepping stone to higher office, are overwhelmingly male and have changed only minimally over the last two or three decades. Men have comprised between $75 \%$ and $80 \%$ of state legislatures, a typical pathway to Congress, since the early 1990s. Even after the electoral gains in 2018 , men still make up $71 \%$ of state legislators. At the local level, more than $78 \%$ of mayors of U.S. cities with populations over 30,000 are men (CAWP 2019). Figures from the National League of Cities show that, in 2001 , men made up $75 \%$ of city councilors in small cities and $64 \%$ in medium and large cities, and there was no more gender diversity in 2001 than in 1979 (NLC 2018).

Men are overrepresented in the careers that feed into politics as well. Law has long been a common path to politics. Bonica (2020) shows that, even when compared with other professionals, lawyers are much more likely to run for office and much more likely to win. While female enrollment in law schools has been near parity with male enrollment since the late 1990s, the legal profession is still majority male (ABA 2000; 2017). Data from the American Bar Association show that men make up $64 \%$ of practicing attorneys (ABA 2017). Among judges, men comprise $67 \%$ of federal

\footnotetext{
${ }^{3}$ Allen and Cutts (2017) and Davidson-Schmich (2016) include the decision to run in the British and German cases, respectively, but neither considers the rate of entry that would be needed for gender parity. Studies also vary in whether they consider nascent, static, or progressive ambition, but regardless of the type of ambition, there is little discussion of how much more ambitious women would need to be for the gender gap in candidates to close.
}

district court judges and $69 \%$ of state court judges (ABA 2017; NWLC 2016). Besides law, many candidates have backgrounds in business. The same pattern holds: data from the 2016 Annual Survey of Entrepreneurs show that about $80 \%$ of businesses nationwide are owned by men (U.S. Census 2018). The figures are also dismal in the military, which has historically been an avenue to politics, where men constitute $84 \%$ of the enlisted forces and $82 \%$ of the officer corps (Reynolds and Shendruk 2018).

To be sure, the professional pathways to some offices do differ for men and women. Carroll and Sanbonmatsu $(2013,23)$ show that $18 \%$ of female state representatives had backgrounds in education and $9 \%$ of women had backgrounds in law. By comparison, $11 \%$ and $14 \%$ of male representatives had backgrounds in education and law, respectively. ${ }^{4}$ Deckman's (2007) survey of school board members finds that $21 \%$ of women are educators, compared with $12 \%$ and $11 \%$ who are executives and professionals, respectively. However, women teachers outnumber women lawyers in the workforce nine to one (U.S. Department of Labor 2017), and across samples of officeholders and candidates, the ratio of women teachers to lawyers does not come close to this margin. Among current U.S. House members, more women have backgrounds in law than education (32\% vs. $26 \%$; Chinoy and Ma 2019), despite the disparity in workforce patterns. We fully expect the pipeline to vary by office, and in contexts where more legislators do come from female-dominated professions, we would expect to see more women in office than in contexts where more legislators come from male-dominated professions (see Crowder-Meyer 2013). We leverage variation in occupational pathways to office in state legislatures later in the article to explore this possibility.

Apart from the professional pathways to office, men are more prominent actors in electoral politics too. Women are as likely to vote as men and report similarly high levels of political interest, but men are more likely to donate money and they give far more than women (Burns, Schlozman, and Verba 2001; Lawless and Fox 2010; Thomsen and Swers 2017). At the congressional level, male donors give more than twice as much money to incumbent Democrats and three times as much to incumbent Republicans (Thomsen and Swers 2017). Bonica and Sen (2017) find that $31 \%$ of female lawyers have donated to candidates, compared with $49 \%$ of male lawyers. Because men are already overrepresented in the legal profession, the disparity in donations results in a much larger number of male lawyers who are engaged in elite-level electoral politics. DavidsonSchmich $(2016,88)$ draws on a unique survey of elite political actors in Germany - party leaders at the grassroots level-and finds that party groups there, too, are

\footnotetext{
${ }^{4}$ Franceschet and Piscopo (2014) similarly show that, in Argentina, women politicians are less likely to be lawyers and businesspeople and more likely to be teachers and activists (but see Schwindt-Bayer 2011). The pathways to office are likely to vary across countries, and potential candidate pools should be tailored to the particular context.
} 
mostly men $(65 \%$ on average; $73 \%$ in parties without quotas).

Indeed, scholars of comparative politics have given significant attention to how the presence of women in the labor force - another way to measure the eligibility pool or the supply of women candidates - is related to cross-national variation in female representation (i.e., Iversen and Rosenbluth 2010; Matland 1998; Moore and Shackman 1996; Rule 1987). Kenworthy and Malami (1999) find that the share of women in professional occupations is associated with the number of women in office, but the share of women in the general labor force is not. Norris and Lovenduski (1995) also argue that the traditional pathways to office hinder the entry of women because women are often concentrated in occupations that are less likely to provide the time, flexibility, financial security, and networks that enable political careers. Recent studies of quotas additionally point to the importance of the pipeline in the advancement of women to leadership positions. O'Brien and Rickne (2016) show that quotas are especially effective when they increase the number of women in the pool from which leaders are selected (see also O'Brien 2015). We build on these insights, but our empirical approach instead considers the gender skew in the pipeline alongside rates of entry due to the emphasis on candidate emergence in the American context in recent years.

In sum, while the routes to some offices differ for men and women, the most common pathways to office for men and women alike are overwhelmingly male. Moreover, the percentage of women in state legislatures with law or business backgrounds has increased since the 1980s (Carroll and Sanbonmatsu 2013) and so has the percentage of women in Congress with state legislative backgrounds (Elder 2008). As a result, we think it is worth examining the decision to run for office within the gendered pipeline to power. The vast majority of elected officials come through tried and true pathways. One common pipeline includes those in lower-level positions who are well situated to seek higher office. Another pipeline includes individuals who work in the professions that often feed into politics, particularly law. Other pipelines include those who are influential actors in elections. Women are grossly outnumbered in all of these, and the gender disparity across a variety of potential candidate pools has important implications for the number of men and women who run.

The selection of men into the traditional pathways to office may in part reflect the gender differences in political ambition that Lawless and Fox (2010) uncover. It is plausible that young people select into careers and activities based on their latent desire to hold office, and Fox and Lawless's $(2014,511)$ own research highlights a gendered winnowing of career interests in college. In this way, our argument is compatible with a variant or extension of the ambition argument that emphasizes the screening out of women from politics before they enter the pipeline rather than once they are there. Yet as it is currently stated, the ambition model gives little attention to any implications of its argument for the supply of women and men in the eligibility pool, which, notably, is reflected in the use of gender-balanced samples of potential candidates. And perhaps most importantly, we depart from the main expectation that underlies ambition research - that equal rates of entry will close the gender gap in candidates-precisely because of the gender skew in the pipelines to office that we emphasize here.

\section{POTENTIAL CANDIDATE POOLS}

We draw on three distinct potential candidate pools to examine rates of entry within the gendered pipeline to power. While each has strengths and weaknesses, we leverage these data to better understand how the gender makeup of the potential candidate pool continues to matter for women's underrepresentation. The first pool includes 30,000 state legislators who are well situated to run for the U.S. House (Thomsen 2017). We use Bonica's (2014) data to identify the sample of state legislators from 2000 to 2010 . This design is typical in studies of candidate entry, as serving in lower-level office often provides individuals with the skills and resources to run for higher office (i.e., Jacobson 1989; Jacobson and Kernell 1983). State legislatures are the most common stepping stone to the House, and more than half of House members came through this pathway (Manning 2016). There is no significant gender or party difference in the percentage of members of Congress with state legislative backgrounds either: $50 \%$ of men and $55 \%$ of women, and $51 \%$ of Democrats and $52 \%$ of Republicans, have state legislative experience (Carnes 2012).

The pool of state legislators offers insight into progressive ambition, or the decision to run for higher office (Schlesinger 1966). Yet it is also the case that candidates come from other avenues (Carroll and Sanbonmatsu 2013), and we seek to examine gender differences beyond previous officeholders as well. Our second pool includes 3,000 individuals, all nonincumbents, who are identified in local and statewide newspapers as potential U.S. Senate candidates for all 611 primary elections from 1994 to 2010 (King 2017). The local knowledge that journalists have of the political landscape results in a unique pool of potential candidates who are much closer to the decision to

\footnotetext{
${ }^{5}$ The potential Senate candidate dataset was not constructed based on occupation, but we also explored whether the men and women in this sample have distinct occupational backgrounds in light of Carroll and Sanbonmatsu's (2013) findings. In this dataset, the percentage of women with backgrounds in law, education, and business is 23,20 , and $25 \%$, respectively. The percentage of men with backgrounds in each is 35,9 , and $30 \%$, respectively. Thus, while women are more likely to have backgrounds in education than men, it is also the case that more women in this sample come from law than education, despite their much lower numbers among employed women. For the Senate pool, we additionally considered the possibility that journalists are more likely to name men than equally qualified women. We examined whether male U.S. House members in a state were more likely to be named in newspapers than female House members, but we found no indication of gender differences.
} 
TABLE 1. Rates of Entry and Number of Potential Candidates across Pools and By Party

\begin{tabular}{|c|c|c|c|c|c|c|}
\hline \multirow{2}{*}{$\begin{array}{l}\text { Sample: } \\
\text { Source: } \\
\text { Office sought: } \\
\text { All }\end{array}$} & \multicolumn{2}{|c|}{$\begin{array}{c}(1) \\
\text { State legislators } \\
\text { Thomsen (2017) } \\
\text { U.S. House }\end{array}$} & \multicolumn{2}{|c|}{$\begin{array}{c}(2) \\
\text { Named in newspapers } \\
\text { King (2017) } \\
\text { U.S. Senate }\end{array}$} & \multicolumn{2}{|c|}{$\begin{array}{c}(3) \\
\text { Lawyer-donors } \\
\text { Bonica and Sen (2017) } \\
\text { State or federal office }\end{array}$} \\
\hline & Women & Men & Women & Men & Women & Men \\
\hline Rate of entry (\%) & 1.4 & 1.5 & $48.6^{\star \star}$ & 56.2 & $0.5^{\star \star}$ & 0.7 \\
\hline Raw number & 7,099 & 23,883 & 432 & 2,558 & 83,819 & 295,719 \\
\hline Total candidates & 101 & 349 & 210 & 1,437 & 392 & 2,109 \\
\hline Democrats & Women & Men & Women & Men & Women & Men \\
\hline Rate of entry (\%) & 1.2 & 1.1 & 50.2 & 55.2 & $0.4^{\star \star}$ & 0.6 \\
\hline Raw number & 4,646 & 11,899 & 243 & 1,160 & 67,005 & 190,520 \\
\hline Total candidates & 56 & 126 & 122 & 640 & 285 & 1,195 \\
\hline Republicans & Women & Men & Women & Men & Women & Men \\
\hline Rate of entry (\%) & 1.8 & 1.9 & $46.6^{\star *}$ & 57.0 & $0.6^{\star \star}$ & 0.9 \\
\hline Raw number & 2,453 & 11,984 & 189 & 1,398 & 16,814 & 105,199 \\
\hline Total candidates & 45 & 223 & 88 & 797 & 107 & 914 \\
\hline
\end{tabular}

run, and this sample allows us to uncover gender disparities in the late stages of candidate entry. These individuals come from a variety of backgrounds, ranging from novices to career politicians. Specifically, $55 \%$ have held elected office and $45 \%$ have not, which shows journalists' coverage of potential candidates extends beyond well-known political figures. This sample is especially valuable for examining women's underrepresentation in the Senate because female senators are less likely to follow the traditional pathway from the U.S. House to the Senate than male senators. ${ }^{6}$

The pools above offer a window into those who are among the most likely to run for Congress. However, because these women already have an interest in running, they may flatten gender differences in rates of entry. We draw on a third sample of nearly 400,000 lawyers who made political contributions (Bonica and Sen 2017). Lawyers are 54 times more likely to run for Congress than the average American, and lawyer-donors are particularly influential because they provide early money that signals candidate viability (Bonica 2020). Law is a common pipeline to Congress for both men and women: $40 \%$ of men and $30 \%$ of women who were elected to the U.S. House from 2010 to 2014 had law degrees $(p<0.05$; calculated by authors with data from Bonica 2020), and the gap has further decreased since (38\% of men and $31 \%$ of women in the 116 th House have law degrees; Chinoy and Ma 2019). Moreover, male and female lawyers alike are more likely to win than nonlawyers (Bonica 2020). Among nonincumbent winners from 2010 to $2014,36 \%$ of women and $35 \%$ of men had law degrees (calculated by authors with data from Bonica 2020). We use the sample of lawyer-donors in the 2012 Martindale-Hubbell directory that Bonica and Sen (2017) combined with FEC records, and we merged them

\footnotetext{
${ }^{6}$ In the $112-116$ th congresses, $53 \%$ of male senators and $37 \%$ of female senators had House experience.
}

with Bonica's (2014) DIME dataset to identify whether they ran for state or federal office from 2000 to $2016 .^{7,8}$

Descriptive statistics of the three pools are provided in Table 1. Rates of entry and the total number of individuals are shown by party. The variation in rates of entry reflects the nature of the samples, but the bivariate gender differences within each pool are not especially large. Among the state legislators, $1.4 \%$ of women and $1.5 \%$ of men ran for the House, and no statistically significant gender differences emerge by party. ${ }^{9}$ Because the potential Senate candidates have been named as likely candidates, their rates of emergence are much higher. The gender disparity is statistically significant but not especially large $-49 \%$ of women and $56 \%$ of men ran-and it is not significant among Democrats. Among lawyer-donors, women are statistically less likely to run for office than men, but the

\footnotetext{
${ }^{7}$ Offices are coded by the Federal Election Commission. State-level offices include state-level executive and legislative offices; judicial offices are excluded because not all judicial candidates need to raise money so their coverage in the DIME data is more limited. Federallevel offices include the presidency, the U.S. House, and the U.S. Senate. In Appendix A, we provide a full discussion of how we validated this measure.

${ }^{8}$ Lawyer-donors are coded as Republicans (Democrats) if they give more than half of their donations to Republican (Democratic) candidates. The vast majority contribute to one party: the lawyer-donors coded as Democrats give, on average, $96 \%$ of their donations to Democrats, and those coded as Republicans give $94 \%$ of their donations to Republicans. About $12 \%$ of the lawyer-donors who ran did so as Independents, but they are coded as Democrats or Republicans if they fit the criteria above. The results are the same when they are excluded. ${ }^{9}$ This differs from the finding in Brown et al. (2019), who use an RDD to show that the effect of state legislative service on running for Congress is twice as large for men as women. However, their sample is limited to mixed-gender close elections and is not reflective of the gender makeup of state legislative candidates. As a result, they are unable to consider how much more likely to run women would need to be to reach parity with men.
} 
difference is not overwhelming: $0.5 \%$ of women and $0.7 \%$ of men ran for state or federal office. Had women run at the same rate as men, this would have resulted in 195 more female candidates in this 16-year period, or about 20 per cycle. But male candidates still would have outnumbered women nearly fourfold.

Gender differences, or a lack thereof, in average rates of running can obscure gender and partisan disparities in the raw number of men and women in each pool. Among the state legislators, there are 11,899 Democratic men and 11,984 Republican men, compared with 4,646 Democratic women and 2,453 Republican women. Women make up an even smaller proportion of likely Senate candidates. In this sample, there are 1,160 Democratic men and 1,398 Republican men, compared with 243 Democratic women and 189 Republican women. Men dominate the pool of lawyer-donors as well: of the 379,538 lawyer-donors, 190,520 are Democratic men, 105,199 are Republican men, 67,005 are Democratic women, and 16,814 are Republican women. This gender skew has serious implications for the number of male and female runners, above and beyond statistically significant gender differences in rates of entry. To be sure, scholars can and do draw on a variety of potential candidate pools to study political ambition and candidate emergence. The strength of these pools is that they allow us to examine individuals with traditional and nontraditional backgrounds and those with varying likelihoods of running for different offices.

Although we do not delve into why these pools are male dominated, we use the year that lawyer-donors were admitted to the bar to look at the gender composition by age cohort in this sample (Bonica and Sen 2017). The average female lawyer-donor is 23 years into her career, or probably around 50 years old. Among Democrats, women make up 36\% of lawyerdonors who are less than 23 years into their careers but only $21 \%$ of those in the profession for longer. Among Republicans, women comprise $21 \%$ of lawyer-donors who are less than 23 years into their careers and a mere $10 \%$ of those in the profession for longer. Much of this reflects the entry of more women into law over time, but some of it may be due to women exiting as well. We also split the sample in Table 1 to examine candidate emergence among lawyer-donors by age, and the gender gap is far more pronounced among younger lawyer-donors. ${ }^{10}$ Even so, we think the larger number of younger women bodes much better for the future of women's representation. The many reasons why there are fewer women in the pipeline are beyond the scope of our analysis, but we are more interested in how the gender makeup of any typical pathway to office interacts with gender disparities in candidate emergence.

\footnotetext{
${ }^{10}$ Rates of entry for women and men in the first 23 years of their careers are $0.4 \%$ and $0.9 \%$, respectively, whereas the rate of entry for both women and men in the profession for longer is $0.6 \%$. This pattern is consistent with research showing that older women are more likely to run for office because their family responsibilities have diminished (Carroll and Sanbonmatsu 2013; see also Teele, Kalla, and Rosenbluth 2018).
}

\section{WOMEN HAVE TO BE FAR MORE LIKELY TO RUN THAN MEN}

The main benefit of using samples that reflect the actual gender makeup of the pipeline is that we can examine the rate at which women would need to run to match the number of male candidates. The gray bars in Figure 1 show the rates of entry for male and female state legislators (left panel) and lawyer-donors (right panel) for the full sample and by party. ${ }^{11}$ The black bars depict the rate at which women would need to run to reach parity with men given the gender makeup of the pools. As noted above, in the sample of state legislators, $1.5 \%$ of men and $1.4 \%$ of women ran for the U.S. House, which resulted in 349 male candidates and 101 female candidates. If women had run at the same rate as men, the number of women candidates would have increased to 106, but this falls far short of the number of men. In fact, women would have to be three times more likely to run than men to match the number of male candidates ( $4.9 \%$ vs. $1.5 \%)$. The partisan disparities are even starker due to the dearth of GOP women. To reach parity with men, Republican women would have to be nearly five times more likely to run than their male co-partisans $(9.1 \%$ vs. $1.9 \%)$, whereas Democratic women would need to be nearly two and a half times more likely to do so than Democratic men $(2.7 \%$ vs. $1.1 \%)$.

In the sample of lawyer-donors, $0.7 \%$ of men and $0.5 \%$ of women ran for state or federal office, which amounted to 2,109 male candidates and 392 female candidates. Here, too, women would have to be three and a half times more likely to run than men to match the number of male candidates $(2.5 \%$ vs. $0.7 \%)$. If we split the sample by party, we see the same pattern as in the sample of state legislators: among Democrats, $0.6 \%$ of men and $0.4 \%$ of women ran for office, which totaled 1,195 men and 285 women candidates. Democratic women would have to be three times more likely to run than Democratic men to reach parity $(1.8 \%$ vs. $0.6 \%)$. Among Republican lawyer-donors, $0.9 \%$ of men and $0.6 \%$ of women ran, which totaled 914 male and 107 female candidates, but Republican women would have to be six times more likely to run than their male co-partisans to equal the number of men $(5.4 \%$ vs. $0.9 \%)$.

In Appendix B, we more fully examine the relationship between gender and candidate emergence across these samples and account for a variety of electoral and partisan factors. We do not present those results here because they are less directly relevant for our argument, but the relationships are similar to those in Table 1. In the pool of state legislators and potential Senate candidates, there is no significant gender difference in the likelihood of running for office, and in the pool of lawyer-donors, women are significantly less likely to run for state and federal office than their male

\footnotetext{
${ }^{11}$ The potential Senate candidates are not shown in Figure 1 because even if all 432 women had run, the number of male candidates still would have tripled the number of female candidates.
} 
FIGURE 1. Women Have to Be More Likely to Run Than Men to Equal the Number of Male Candidates, Especially among Republicans
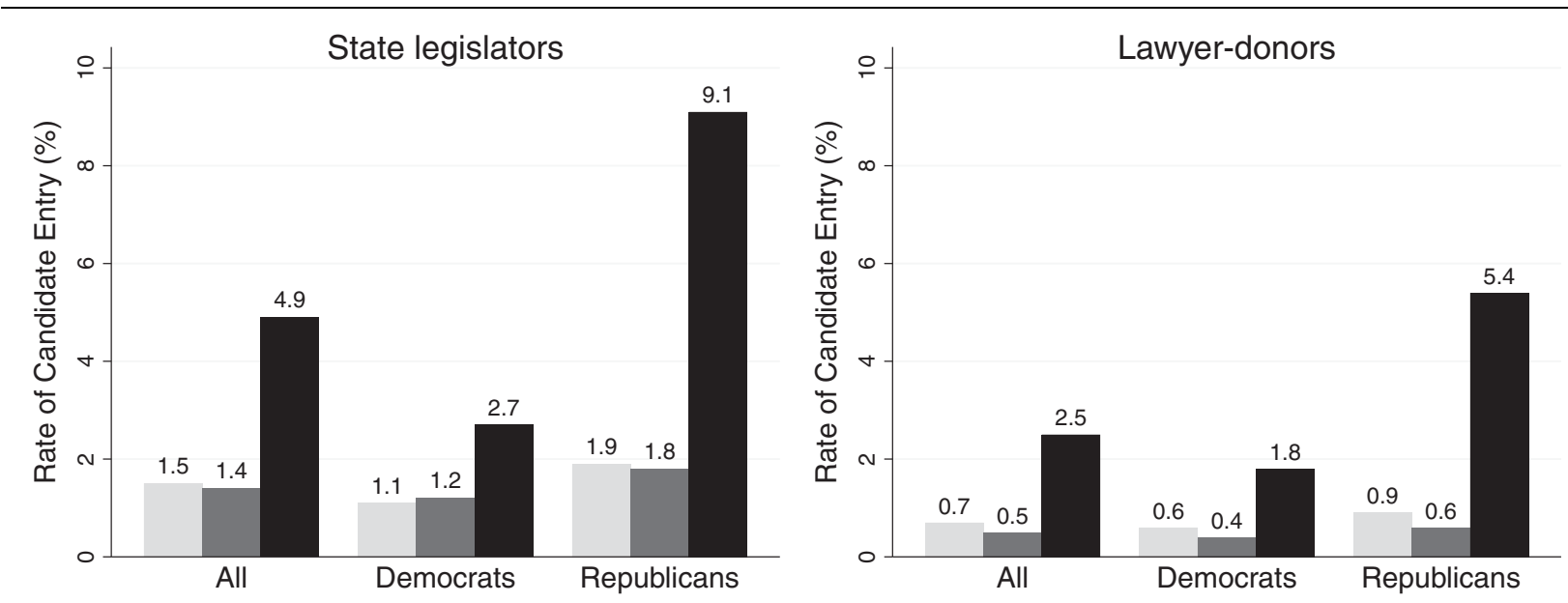

Men, Actual

Women, Actual

Women, Needed for Parity

Men, Actual

Women, Actual

Women, Needed for Parity

Note: Rates of entry are calculated from the samples of state legislators and lawyer-donors used in Table 1.

counterparts. A full description of the data and variables is provided in Appendix B. ${ }^{12}$

The size of the "return" on equal rates of entry-that is, the number of additional women who would runvaries depending on the actual disparity in these rates and the number of women in the pipeline. The advantage of the design here is that we are able to measure both of these. Table 2 shows how the overall number of women candidates would change in these pools if women's rates of entry were the same as men's. If women state legislators had sought higher office at the same rate as men, the number of female House candidates would have increased only minimally, from 101 to 106. By comparison, the returns are larger in the Senate pool and the lawyer-donor pool. In the Senate pool, equal rates of entry would have resulted in an increase of 32 women candidates (from 210 to 242). In the lawyer-donor pool, if women had run at the same rate as men, the number of women would have risen by 195, from 392 to 587 . Yet we want to emphasize that, in all of these scenarios, equal rates of entry would still

\footnotetext{
${ }^{12}$ We also used Palmer and Simon's (2012) measure of womenfriendly congressional districts to examine districts with demographic profiles that are more favorable to the election of women-namely, more urban, diverse, and wealthier districts. We interacted womenfriendly district with gender to see if women were more likely to run in these districts, but the interaction is insignificant across models (see Appendix C). However, women do make up a greater proportion of the sample in women-friendly districts. Women comprise $29 \%$ of the sample of state legislators in more women-friendly districts (measured as the median and above), vs. $17 \%$ in less women-friendly districts. As a result, the pool of likely women candidates is much larger, which lends additional support to the argument that the gender makeup of the eligibility pool plays a key role in patterns of women's representation.
}

result in dramatically more male candidates than female candidates.

Table 2 also illustrates how the number of women candidates would change if women ran at the same rate as in our samples but instead comprised half of each pool. In all three pools, the number of women candidates would double, triple, or quadruple the number of actual women candidates regardless of whether women were less likely to run than men. One implication is that women's organizations and candidate training programs could focus their attention on, for example, the kinds of legal careers that attract more women, because even small increases in rates of entry would translate into larger numbers of women candidates.

For those concerned about gender parity in both parties, the dearth of Republican women candidates is likely to be a persistent problem due to the lack of GOP women in the pipeline. The findings echo those in Crowder-Meyer and Lauderdale (2014), who similarly show that Republican women are dramatically outnumbered among potential candidates. For the most part, scholars have examined the growing partisan gap in women's representation through the lens of fundraising patterns, regional realignments, and ideological changes in the parties (i.e., Crowder-Meyer and Cooperman 2018; Elder 2008; Thomsen 2017; Thomsen and Swers 2017). Yet the disparity across pools sheds light on the distinct benches of the two parties and suggests that solutions to underrepresentation will likely differ by party as well. To elect Republican women, organizations may want to identify a number of targets and throw their support behind these individuals. On the Democratic side, resources could be more evenly distributed across women due to their larger numbers. Scholars in multiparty systems might also consider different 
TABLE 2. How Rates of Entry and Supply Affect the Number of Women Candidates

\begin{tabular}{lccc}
\hline $\begin{array}{l}\text { Sample: } \\
\text { Office sought: }\end{array}$ & $\begin{array}{c}(1) \\
\text { State legislators } \\
\text { U.S. House }\end{array}$ & $\begin{array}{c}(2) \\
\text { Named in newspapers } \\
\text { U.S. Senate }\end{array}$ & $\begin{array}{c}\text { (3) } \\
\text { Lawyer-donors } \\
\text { State or federal office }\end{array}$ \\
\hline All & & & 210 \\
Women candidates, actual & 101 & 242 & 392 \\
If rate of entry equaled men's & 106 & 732 & 587 \\
If women comprised half of pool & 217 & & 949 \\
& & 122 & 285 \\
Democrats & 56 & 351 & 402 \\
Women candidates, actual & 51 & & 515 \\
If rate of entry equaled men's & 99 & 88 & 107 \\
If women comprised half of pool & & 373 & 151 \\
Republicans & 45 & 366 \\
Women candidates, actual & 47 & 30 & \\
If rate of entry equaled men's & 130 & & \\
If women comprised half of pool & & & \\
\hline
\end{tabular}

prescriptions by party depending on the gender makeup of the pipelines to office.

\section{EXPANDING THE OCCUPATIONAL PATHWAYS TO OFFICE}

Another way to increase women's representation that departs from the analyses above is to change what the pipeline professions are. Over two decades ago, Darcy, Welch, and Clark (1994, 112) wrote, "Women's occupations and activities have not provided the same sort of gateway to political office as prestigious male occupations." Indeed, women and men alike still enter office through male-dominated professions, but there are important differences across legislative institutions with respect to occupational pathways. In the American context, some state legislatures have more teachers in office, while others have more lawyers and business owners. ${ }^{13}$ One implication of our argument is that women should make up a greater proportion of legislators in states where more officeholders come from female-dominated occupations like education and health care, and women should make up a smaller proportion of legislators in states where more officeholders come from male-dominated occupations like law and business. ${ }^{14}$ We could also leverage variation in pathways to office across countries to test whether

\footnotetext{
${ }^{13}$ Due to data limitations, we are unable to compare average rates of entry for teachers and lawyers. Teachers are less likely to run for office than lawyers given their numbers in office compared with their numbers in the workforce, but we are unable to evaluate how much more likely to run teachers would need to be for the gender gap to diminish.

${ }^{14}$ Another implication is that women should make up a greater proportion of state and federal (congressional) candidates when they comprise a greater proportion of lawyer-donors (state legislators). We find preliminary support for this expectation. The results are not shown here due to space constraints but are provided in Appendix D.
}

women's representation increases when more legislators come from female-dominated professions.

To briefly examine this possibility within the United States, we draw on occupational data from the National Conference of State Legislatures that extend over four years (1993, 1995, 2007, and 2015). The dependent variable is the percentage of women in state legislative office. The independent variables are the percentages of legislators with backgrounds in law, business, education, homemaking, health care, and agriculture. State and year fixed effects are also included in the model. Other factors certainly play a role in these patterns, but the relationships in Table 3 conform to expectations. Women's representation is lower in contexts where more legislators have backgrounds in law and higher in contexts where more legislators have backgrounds in education and homemaking.

Figure 2 shows the predicted values of women's representation in state legislatures as the percentage of lawyers and educators changes. An increase from the minimum to the maximum percentage of legislators with backgrounds in law corresponds to a nine percentage point decrease in the percentage of women in office. A similar increase in the percentage of legislators with backgrounds in education corresponds to a four point increase in the percentage of female legislators. To provide historical perspective, it has taken nearly three decades for the average level of women's representation in state legislatures to increase by nine percentage points. With the exception of 2018, the largest singleyear increase in women's representation in state legislatures since the early 1990s has been one percentage point (CAWP 2019). The historic 2018 elections resulted in a three and a half point increase in women's representation in state legislatures and a three point increase in women's representation in Congress (CAWP 2019).

In light of the significant gains made in 2018, particularly among Democratic women, we briefly consider the 2018 election in the context of our argument about the gender skew in the pipelines to office. We examine 


\section{TABLE 3. Occupational Pathways to Office} and Women's Representation

\begin{tabular}{lc}
\hline & $\begin{array}{c}\text { Percentage of women } \\
\text { in state legislature }\end{array}$ \\
\hline Law & $-0.24^{\star \star}$ \\
Business & $(0.08)$ \\
& -0.12 \\
Education & $(0.06)$ \\
& $0.20^{*}$ \\
Homemaking & $(0.09)$ \\
& $0.94^{\star *}$ \\
Health Care & $(0.32)$ \\
& 0.21 \\
Agriculture & $(0.17)$ \\
& -0.14 \\
Constant & $(0.11)$ \\
& $10.64^{\star *}$ \\
Observations & $(3.14)$ \\
$R^{2}$ & 200 \\
& 0.89 \\
Note: Entries are OLS regression coefficients with standard \\
errors in parentheses. The dependent variable is the percentage \\
of women in state legislative office. NCSL occupational data are \\
for all states in 1993, 1995, 2007, and 2015. The model includes \\
state and year fixed effects. ${ }^{* *} p<0.01,{ }^{*} p<0.05$. \\
\hline
\end{tabular}

whether 2018 was unique in terms of the occupational pathways to office for women candidates. If the professional backgrounds of women runners or winners were distinct in 2018, it may indicate either that the election was an outlier or that the traditional avenues to office have shifted. However, if the women who ran and were elected in 2018 had similar backgrounds as those in previous years, it would suggest that contextual factors like the election of Donald Trump, the \#MeToo movement, and the general sense that sexism became more brazen in American politics after the 2016 elections are a better explanation for the increase in women's candidacies in 2018 than changes in the typical pathways to office. $^{15}$

We use data from Project Vote Smart to compare the backgrounds of the women who ran for the U.S. House in 2018 with those who ran in the previous four elections (2010-16). We focus on nonincumbent Democratic women since they drove the 2018 gains, with occupations divided into education, law, business, and health care. The number of women increased across these occupation types, but their makeup was not much different than in the previous four cycles. In 2018, 31\% had backgrounds in education, $16 \%$ in law, $35 \%$ in business, and $10 \%$ in health care, whereas from 2010 to 2016 , these percentages averaged $31,20,29$, and $10 \%$, respectively. The makeup of female winners also did not differ: newly elected women were not more

\footnotetext{
${ }^{15}$ Dittmar (2020) finds that almost half of all Democratic nonincumbent female House candidates expressed urgency, anger, frustration, or threat in explaining why they ran for office in 2018. Just one in five GOP women described any of these feelings as motivating their candidacies.
}

likely to have backgrounds in education or health care than women elected prior to 2018, nor were they less likely to have law or business backgrounds. Furthermore, and similar to other years, women lawyers from both parties were more likely to be elected to office than women nonlawyers ( $23 \%$ vs. $7 \%$ in 2018 , compared with $13 \%$ vs. $5 \%$ in $2010-16$ ). In fact, of the women currently serving in the House, $39 \%$ of the women elected in 2018 have law degrees compared with $27 \%$ of the women elected in other years (Chinoy and Ma 2019). These patterns make our argument even more compelling given our emphasis on the dearth of women in the traditional pathways to office.

One key factor that shaped women's success in 2018 was that Democratic women were far more likely to win. Indeed, the primary victory rate of Democratic women doubled that of their male co-partisans (CAWP 2019). Among Democratic lawyers in our occupational data, women were nearly three times more likely to be elected than men ( $28 \%$ and $10 \%$, respectively) and also more likely to be elected than women in previous years ( $28 \%$ and $14 \%$, respectively). Among Democratic nonincumbents who won in 2018, the raw number of women with law degrees actually surpassed the number of men with law degrees (14 and 12 , respectively; Chinoy and Ma 2019). Thus, while more women ran for office, it is clear that demand-side factors favoring the election of women contributed to their successes as well. Despite these gains, we think a more reliable path to gender parity in legislative office is one in which the number of male and female candidates is equal.

It is important to note that we are not arguing that legislators should have backgrounds in law or business rather than education. To the contrary, we think the traditional pathways to office are a hindrance to the election of women. Moreover, there is ample evidence of the representational and policy drawbacks of the overrepresentation of lawyers and white-collar professionals in politics (Bonica 2020; Carnes 2013; 2018). Our argument is instead that since many male and female candidates do come through male-dominated pipelines, we need to more seriously consider gender disparities within these pathways to understand the continued underrepresentation of women and Republican women in particular.

\section{CONCLUSION}

Over the last two decades, most of the gender research in American politics has focused on the reasons for the ambition gap between men and women and various ways to foster women's political ambition. There is substantial evidence across studies that recruitment and support from party and community leaders is a crucial mechanism for the advancement of women in politics. Candidate training programs have emerged within the United States and abroad to help translate women's political interest into candidacies (Kreitzer and Osborn 2019; Piscopo 2019; Sanbonmatsu 2015). These efforts are invaluable for encouraging the near runners to throw their hats in the ring. However, we 


\section{FIGURE 2. Lawyer-Legislators (Educator-Legislators) are Negatively (Positively) Associated with Women's Representation}
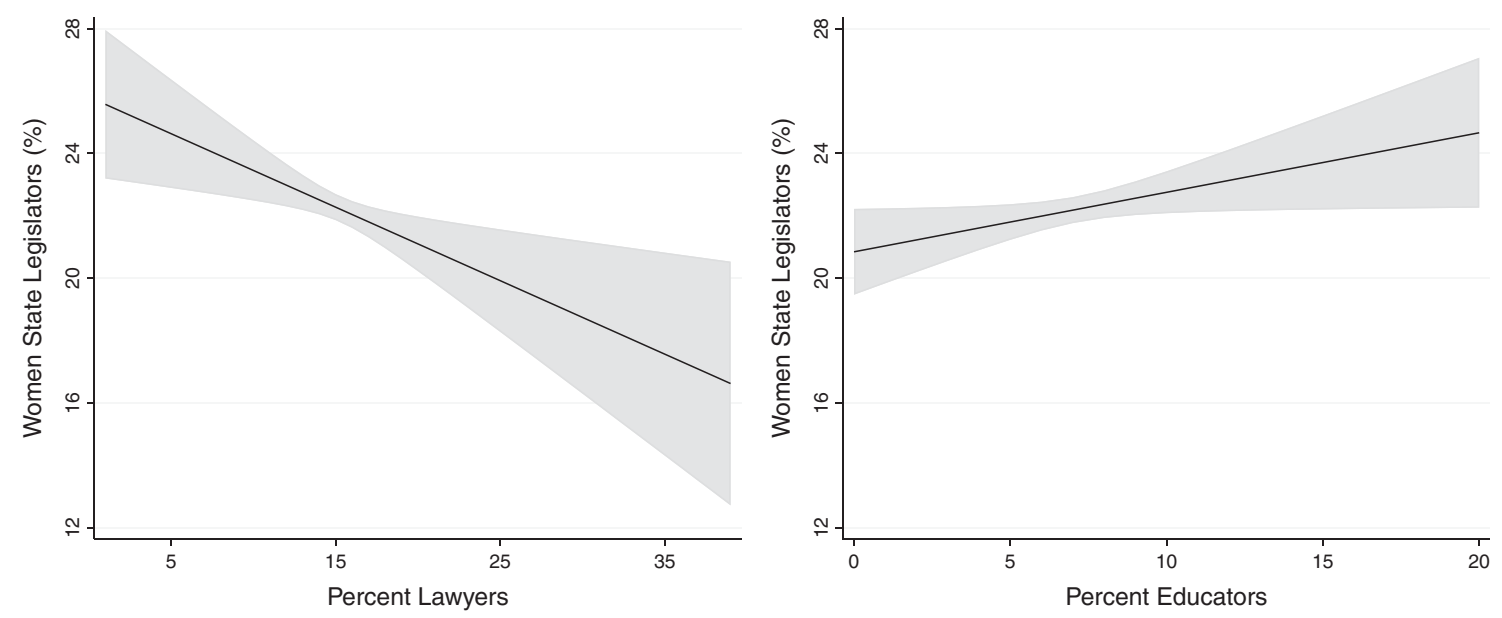

Note: Values are calculated from the model in Table 3.

think the hurdles to gender equality in legislative institutions are greater than the ambition deficit, and we are skeptical that equal rates of running will result in an equal number of male and female candidates.

In this article, we leveraged a variety of datasets to shed new light on how the gender skew in the potential candidate pool continues to matter for the election of women to office in the American context. Although educational and labor force patterns have changed over time, the pipeline to political power remains overwhelmingly male. As a result, women have to be far more likely to run for office than men for the gender gap in candidates to close, particularly on the Republican side. The upshot is that women need to have higher levels of political ambition, lower levels of election aversion, and be more likely to be recruited than men to reach gender parity. An additional question for future studies of candidate emergence-within the gender and politics subfield and beyond-is whether potential candidate pools should be based on those who are most likely to run, those who are more numerous in the legislature (but may be less likely to run, on average), or those who are most likely to win. These answers are sometimes the same, but not always and not across institutions.

To be sure, the pathways to office and methods of candidate selection vary dramatically by context. Our focus is on the United States, but scholars of comparative politics might similarly examine gender disparities in the potential candidate pools from which party leaders recruit. While quotas have become increasingly common cross-nationally, party gatekeepers can still hamper women's success (i.e., Krook 2016; SchwindtBayer 2009). Importantly, women may be disadvantaged twice: first, in a biased selection rate, and second, due to the overrepresentation of men in the pipeline to office. A clear extension of our findings is that party gatekeepers may need to be more likely to recruit women to achieve gender parity in party lists (see Davidson-Schmich 2016). Some pipelines to office likely include more women than others, and scholars can leverage variation across contexts to examine how the gendered pipeline to office matters for both candidate emergence and recruitment efforts by party leaders.

In sum, the broader goal of this article is to generate a new conversation about how to study women's underrepresentation. First, we think scholars should engage more directly with the actual decision to run or stand for office. There is substantial empirical distance between considering a candidacy and running for office, and we need to know more about gender differences in the decision to run itself. In addition, the gender makeup of the potential candidate pools in our research should more closely mirror that of actual potential candidate pools. Only then can we know whether equal rates of entry are enough to close the gender gap in candidates. We are certainly not the first to highlight the gender skew in the pipeline, but we are the first to consider how rates of entry interact with the pipeline and matter for the number of women who run. We hope that our findings offer a compelling starting point for a renewed discussion of the gendered pipeline to power. Recent empirical advances and the availability of more data across offices make this an increasingly feasible endeavor for scholars of gender and politics.

\section{SUPPLEMENTARY MATERIALS}

To view supplementary material for this article, please visit http://dx.doi.org/10.1017/S0003055420000404. Replication materials can be found on Dataverse at: https://doi.org/10.7910/DVN/FCZDKD.

\section{REFERENCES}

Allen, Peter, and David Cutts. 2017. "Aspirant Candidate Behaviour and Progressive Ambition." Research and Politics 4 (1): 1-9. 
Allen, Peter, and David Cutts. 2020. "Personality and the Gender Gap in Political Ambition." European Journal of Politics and Gender 3 (1): 11-32.

American Bar Association (ABA). 2000. "A Snapshot of Women in the Law in the Year 2000." Accessed February 11, 2019. https:// www.americanbar.org/.

American Bar Association (ABA). 2017. "A Current Glance at Women in the Law." Accessed February 11, 2019. https:// www.americanbar.org/.

Anzia, Sarah F., and Christopher R. Berry. 2011. "The Jackie (and Jill) Robinson Effect: Why Do Congresswomen Outperform Congressmen?" American Journal of Political Science 55 (3): 478-93.

Bauer, Nichole M. 2015. "Who Stereotypes Female Candidates? Identifying Individual Differences in Feminine Stereotype Reliance." Politics, Groups, and Identities 3 (1): 94-110.

Bonica, Adam. 2014. "Mapping the Ideological Marketplace." American Journal of Political Science 58 (2): 367-86.

Bonica, Adam. 2020. "Why Are There So Many Lawyers in Congress?" Legislative Studies Quarterly 45 (2): 253-89.

Bonica, Adam, and Maya Sen. 2017. "The Politics of Selecting the Bench from the Bar: The Legal Profession and Partisan Incentives to Introduce Ideology into Judicial Selection." Journal of Law and Economics 60 (4): 559-95.

Brown, Ryan, Hani Mansour, Stephen D. O'Connell, and James Reeves. 2019. "Gender Differences in Political Career Progression: Evidence from U.S. Elections." IZA Discussion Paper No. 12569.

Burns, Nancy, Kay Lehman Schlozman, and Sidney Verba. 2001. The Private Roots of Public Action: Gender, Equality, and Political Participation. Cambridge, MA: Harvard University Press.

Burrell, Barbara C. 1994. A Woman's Place Is in the House: Campaigning for Congress in the Feminist Era. Ann Arbor: University of Michigan Press.

Carnes, Nicholas. 2012. Congressional Leadership and Social Status (CLASS) Dataset, v. 1.9 [computer file]. Available from the author, nicholas.carnes@duke.edu.

Carnes, Nicholas. 2013. White-Collar Government: The Hidden Role of Class in Economic Policy Making. Chicago: University of Chicago Press.

Carnes, Nicholas. 2018. The Cash Ceiling: Why Only the Rich Run for Office-And What We Can Do about It. Chicago: University of Chicago Press.

Carroll, Susan J. 1994. Women as Candidates in American Politics, 2nd edition. Bloomington: Indiana University Press.

Carroll, Susan J., and Kira Sanbonmatsu. 2013. More Women Can Run: Gender and Pathways to the State Legislatures. New York: Oxford University Press.

Cassese, Erin C., and Mirya R. Holman. 2018. "Party and Gender Stereotypes in Campaign Attacks." Political Behavior 40 (3): 785-807.

Center for American Women and Politics (CAWP). 2019. "Women in Elective Office 2019." New Brunswick, NJ: Center for American Women and Politics. https://cawp.rutgers.edu/women-electiveoffice-2019.

Chinoy, Sahil, and Jessica Ma. 2019. "How Every Member Got to Congress." New York Times January 26. (Raw data sent to authors by Chinoy.)

Crowder-Meyer, Melody. 2013. "Gendered Recruitment without Trying: How Local Party Recruiters Affect Women's Representation." Politics \& Gender 9 (4): 390-413.

Crowder-Meyer, Melody, and Rosalyn Cooperman. 2018. "Can’t Buy Them Love: How Party Culture among Donors Contributes to the Party Gap in Women's Representation." Journal of Politics 80 (4): 1211-24.

Crowder-Meyer, Melody, and Benjamin E. Lauderdale. 2014 "A Partisan Gap in the Supply of Female Potential Candidates in the United States." Research and Politics 1 (1): 1-7.

Davidson-Schmich, Louise. 2016. Gender Quotas and Democratic Participation: Recruiting Candidates for Elective Offices in Germany. Ann Arbor: University of Michigan Press.

Darcy, Robert, Susan Welch, and Janet Clark. 1994. Women, Elections, and Representation, 2nd edition. Lincoln: University of Nebraska Press.

Deckman, Melissa. 2007. "Gender Differences in the Decision to Run for School Board.” American Politics Research 35 (4): 541-63.
Ditonto, Tessa, Allison J. Hamilton, and David P. Redlawsk. 2014. "Gender Stereotypes, Information Search, and Voting Behavior in Political Campaigns." Political Behavior 36 (2): 335-58.

Dittmar, Kelly. 2020. "Urgency and Ambition: The Influence of Political Environment and Emotion in Spurring US Women's Candidacies in 2018." European Journal of Politics and Gender 3 (1): 143-60.

Duerst-Lahti, Georgia. 1998. "The Bottleneck, Women as Candidates." In Women and Elective Office, eds. Sue Thomas and Clyde Wilcox, 15-25. New York: Oxford University Press.

Elder, Laurel. 2008. "Whither Republican Women: The Growing Partisan Gap among Women in Congress." The Forum 6 (1): Article 13.

Fox, Richard L., and Jennifer L. Lawless. 2010. "If Only They'd Ask: Gender, Recruitment, and Political Ambition.” Journal of Politics 72 (2): 310-26.

Fox, Richard L., and Jennifer L. Lawless. 2014. "Uncovering the Origins of the Gender Gap in Political Ambition." American Political Science Review 108 (3): 499-519.

Franceschet, Susan, and Jennifer M. Piscopo. 2014. "Sustaining Gendered Practices? Power, Parties, and Elite Political Networks in Argentina." Comparative Political Studies 47 (1): 85-110.

Fulton, Sarah A. 2012. "Running Backwards and in High Heels: The Gendered Quality Gap and Electoral Success." Political Research Quarterly 65 (2): 303-14.

Holman, Mirya R., Jennifer L. Merolla, and Elizabeth J. Zechmeister. 2016. "Terrorist Threat, Male Stereotypes, and Candidate Evaluations." Political Research Quarterly 69 (1): 134-47.

Iversen, Torben, and Frances Rosenbluth. 2010. Women, Work, and Politics. New Haven, CT: Yale University Press.

Jacobson, Gary C. 1989. "Strategic Politicians and the Dynamics of U.S. House Elections, 1946-1986." American Political Science Review 83 (3): 773-93.

Jacobson, Gary C., and Samuel Kernell. 1983. Strategy and Choice in Congressional Elections, 2nd edition. New Haven, CT: Yale University Press.

Kage, Rieko, Frances M. Rosenbluth, and Seiki Tanaka. 2019. "What Explains Low Female Political Representation? Evidence from Survey Experiments in Japan.” Politics \& Gender 15 (2): 285-309. Kanthak, Kristin, and Jonathan Woon. 2015. "Women Don't Run? Election Aversion and Candidate Entry." American Journal of Political Science 59 (3): 595-612.

Kenworthy, Lane, and Melissa Malami. 1999. "Gender Inequality in Political Representation: A Worldwide Comparative Analysis." Social Forces 78 (1): 235-69.

King, Aaron S. 2017. Unfolding Ambition in Senate Primary Elections: Strategic Politicians and the Dynamics of Candidacy Decisions. Lanham, MD: Lexington Books.

Kreitzer, Rebecca K., and Tracy L. Osborn. 2019. "The Emergence and Activities of Women's Recruiting Groups in the U.S." Politics, Groups, and Identities 7 (4): 842-52.

Krook, Mona Lena. 2016. "Contesting Gender Quotas: Dynamics of Resistance." Politics, Groups, and Identities 4 (2): 268-83.

Lawless, Jennifer L. 2012. Becoming A Candidate: Political Ambition and the Decision to Run for Office. New York: Cambridge University Press.

Lawless, Jennifer L., and Richard L. Fox. 2005. It Takes a Candidate: Why Women Don't Run for Office. New York: Cambridge University Press.

Lawless, Jennifer L., and Richard L. Fox. 2010. It Still Takes a Candidate: Why Women Don't Run for Office. New York: Cambridge University Press.

Lazarus, Jeffrey, and Amy Steigerwalt. 2018. Gendered Vulnerability: How Women Work Harder to Stay in Office. Ann Arbor: University of Michigan Press.

Maisel, L. Sandy, and Walter J. Stone. 2014. "Candidate Emergence Revisited: The Lingering Effects of Recruitment, Ambition, and Successful Prospects among House Candidates." Political Science Quarterly 129 (3): 429-47.

Manning, Jennifer E. 2016. "Membership of the 114th Congress: A Profile." Washington, DC: Congressional Research Service.

Mariani, Mack D. 2008. "A Gendered Pipeline? The Advancement of State Legislators to Congress in Five States." Politics \& Gender 4 (2): 285-308. 
Matland, Richard E. 1998. "Women's Representation in National Legislatures: Developed and Developing Countries." Legislative Studies Quarterly 23 (1): 109-25.

Mo, Cecilia Hyunjung. 2015. "The Consequences of Explicit and Implicit Gender Attitudes and Candidate Quality in the Calculations of Voters." Political Behavior 37 (2): 357-95.

Moore, Gwen, and Gene Shackman. 1996. "Gender and Authority: A Cross-National Study.” Social Science Quarterly 77 (2): 273-88.

National Conference of State Legislatures (NCSL). 2015. "State Legislators' Occupations." Accessed September 10, 2019. (Raw data sent to authors by NCSL staff.)

National League of Cities (NLC). 2018. "City Councils." Accessed February 11, 2019. https://www.nlc.org/city-councils.

National Women's Law Center (NWLC). 2016. "Women in the Federal Judiciary: Still a Long Way to Go." Accessed February 11, 2019. https:/nwlc.org/wp-content/uploads/2015/08/ factsheetnumberofwomeninjudiciary.pdf.

Niven, David. 1998. "Party Elites and Women Candidates: The Shape of Bias." Women and Politics 19 (2): 57-80.

Norris, Pippa, and Joni Lovenduski. 1995. Political Recruitment: Gender, Race and Class in the British Parliament. New York: Cambridge University Press.

O'Brien, Diana Z. 2015. "Rising to the Top: Gender, Political Performance, and Party Leadership in Parliamentary Democracies." American Journal of Political Science 59 (4): 1022-39.

O'Brien, Diana Z., and Johanna Rickne. 2016. "Gender Quotas and Women's Political Leadership." American Political Science Review 110 (1): 112-26.

Palmer, Barbara, and Dennis Simon. 2012. Women \& Congressional Elections: A Century of Change. Boulder, $\mathrm{CO}$ : Lynne Rienner.

Pearson, Kathryn, and Eric McGhee. 2013. "What It Takes to Win: Questioning 'Gender Neutral' Outcomes in U.S. House Elections." Politics \& Gender 9 (4): 439-62.

Piscopo, Jennifer M. 2019. "The Limits of Leaning In: Ambition, Recruitment, and Candidate Training in Comparative Perspective." Politics, Groups, and Identities 7 (4): 817-28.

Piscopo, Jennifer M., and Meryl Kenny. 2020. "Special Issue: Rethinking the Ambition Gap: Gender and Candidate Emergence in Comparative Perspective." European Journal of Politics and Gender 3 (1): 3-10.

Preece, Jessica, and Olga Stoddard. 2015. "Does the Message Matter? A Field Experiment on Political Party Recruitment." Journal of Experimental Political Science 2 (1): 26-35.

Pruysers, Scott, and Julie Blais. 2017. "Why Won't Lola Run? An Experiment Examining Stereotype Threat and Political Ambition." Politics \& Gender 13 (2): 232-52.

Pruysers, Scott, and Julie Blais. 2019. "Narcissistic Women and CashStrapped Men: Who Can Be Encouraged to Consider Running for
Political Office, and Who Should Do the Encouraging?" Political Research Quarterly 72 (1): 229-42.

Reynolds, George M., and Amanda Shendruk. 2018. "Demographics of the U.S. Military." Council on Foreign Relations, April 24 , 2018. Accessed February 11, 2019. https://www.cfr.org/article/ demographics-us-military.

Rule, Wilma. 1987. "Electoral Systems, Contextual Factors and Women's Opportunity to Election to Parliament in Twenty-Three Democracies." Western Political Quarterly 40 (3): 477-98.

Sanbonmatsu, Kira. 2002. "Gender Stereotypes and Vote Choice." American Journal of Political Science 46 (1): 20-34.

Sanbonmatsu, Kira. 2006. Where Women Run: Gender and Party in the American States. Ann Arbor: University of Michigan Press.

Sanbonmatsu, Kira. 2015. "Electing Women of Color: The Role of Campaign Trainings." Journal of Women, Politics \& Policy 36 (2): $137-60$.

Schlesinger, Joseph A. 1966. Ambition and Politics: Political Careers in the United States. Chicago: Rand McNally.

Schneider, Monica C., and Angela L. Bos. 2014. "Measuring Stereotypes of Female Politicians." Political Psychology 35 (2): 245-66.

Schneider, Monica C., Mirya R. Holman, Amanda B. Diekman, and Thomas McAndrew. 2016. "Power, Conflict, and Community: How Gendered Views of Political Power Influence Women's Political Ambition.” Political Psychology 37 (4): 515-31.

Schwindt-Bayer, Leslie A. 2009. "Making Quotas Work: The Effect of Gender Quota Laws on the Election of Women." Legislative Studies Quarterly 34 (1): 5-28.

Schwindt-Bayer, Leslie A. 2011. "Women Who Win: Social Backgrounds, Paths to Power, and Political Ambition in Latin American Legislatures." Politics \& Gender 7 (1): 1-33.

Seltzer, Richard A., Jody Newman, and Melissa Voorhees Leighton. 1997. Sex as a Political Variable: Women as Candidates and Voters in U.S. Elections. Boulder, CO: Lynne Reinner.

Teele, Dawn Langan, Joshua Kalla, and Frances Rosenbluth. 2018. "The Ties That Double Bind: Social Roles and Women's Underrepresentation in Politics." American Political Science Review 112 (3): 525-41.

Thomsen, Danielle M. 2017. Opting Out of Congress: Partisan Polarization and the Decline of Moderate Candidates. New York: Cambridge University Press.

Thomsen, Danielle M., and Michele L. Swers. 2017. "Which Women Can Run? Gender, Partisanship, and Candidate Donor Networks." Political Research Quarterly 70 (2): 449-63.

U.S. Census. 2018. "Number of Women-Owned Employer Firms Increases." Accessed February 11, 2019. https://census.gov/ newsroom/press-releases/2018/employer-firms.html.

U.S. Department of Labor. 2017. "Employment and Earnings by Occupation." Accessed September 20, 2019. https://www.dol.gov/ wb/occupations_interactive_txt.htm. 